
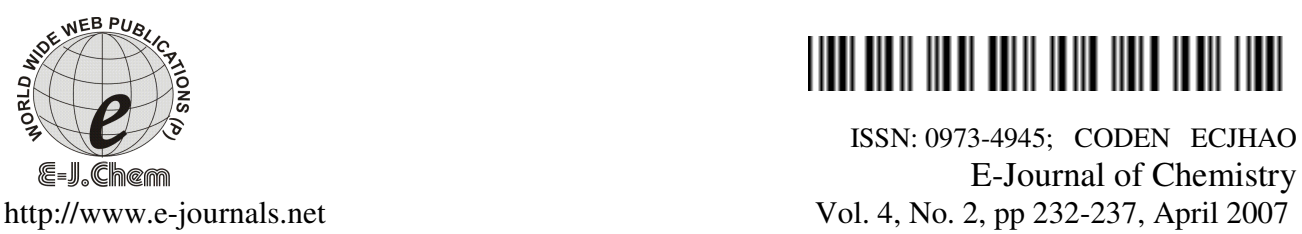

\title{
Microwave Assisted Synthesis Spectral and Antibacterial Investigations on Complexes of Mn(II) With Amide Containing Ligands
}

\author{
N. BHOJAK, * D. D. GUDASARIA, N. KHIWANI and R. JAIN \\ Green Chemistry Research Centre, \\ P.G. Department of Chemistry, \\ Govt. Dungar College (A-Grade), \\ University of Bikaner, Bikaner - 334003.
}

Received 19 November 2006; Accepted 16 December 2006

\begin{abstract}
The present research work describes the synthesis, spectral and antibacterial studies on the complexes of $\mathrm{Mn}$ (II) with amide group containing ligands. Synthesis of complexes has been carried out by conventional method as well as by microwave method. The complexes have been characterized on the basis of elemental analysis, infrared, electronic spectra and magnetic susceptibility studies. The diffuse reflectance spectrums of the complexes show bands in the region $20,000 \mathrm{~cm}^{-1}$ to $26,000 \mathrm{~cm}^{-1}$ assignable to ${ }^{6} \mathrm{~A}_{1 \mathrm{~g}} \rightarrow$ ${ }^{4} \mathrm{~T}_{2 \mathrm{~g}}$ and ${ }^{6} \mathrm{~A}_{1 \mathrm{~g}} \rightarrow{ }^{4} \mathrm{E}_{1 \mathrm{~g}}$ transitions. These are also typical of tetrahedral environment around the manganese. The magnetic moment (5.80 $\mathrm{BM})$ of the complex indicates high spin tetrahedral environment. The microwave method of synthesis of complexes have been found easier, convenient and ecofriendly.
\end{abstract}

Keywords: Manganese(II), microwave, amide ligands

\section{Introduction}

Manganese is essential to organisms and activates numerous enzymes and for certain enzymes there appears to be a high specificity for manganese(II). Deficiency in soils has led to the infertility in mammals bone malformation in growing chicks. ${ }^{1}$ The ability of $\mathrm{Mn}$ (II) to substitute for $\mathrm{Mg}(\mathrm{II})$, a more common physiological cofactor in wide variety of enzymatic reactions has made $\mathrm{Mn}(\mathrm{II})$ popular as a spectroscopic probe for the $\mathrm{Mg}(\mathrm{II})$ site 
in many enzymatic complexes. ${ }^{2}$ Replacement of $\mathrm{Mg}(\mathrm{II})$ by $\mathrm{Mn}(\mathrm{II})$ may have different functional consequences with different enzymes. However, there are a number of similarities in the coordination properties of two ions, and in many cases, the maximal rates of enzymatic reaction activated by $\mathrm{Mn}$ (II) are nearly equivalent to those obtained with $\mathrm{Mg}$ (II). Living organisms can certainly differentiate between the two ions as evidenced by their separate metabolic routes. Thus, $\mathrm{Mn}$ (II) still remains one of the best surrogate for $\mathrm{Mg}$ (II) in studies of enzymic complexes. ${ }^{3}$ Investigations on amide ligands is significant due to their biological and analytical importance. ${ }^{4-6}$

The present research work describes the synthesis, spectral and antibacterial studies on the complexes of $\mathrm{Mn}(\mathrm{II})$ with amide group containing ligands. The complexes have been characterized on the basis of elemental analysis, infrared, electronic spectra and magnetic susceptibility studies.

\section{Experimental}

All the chemicals and solvents used were of AR grade. Purity of synthesized compounds has been checked by thin layer chromatography. IR spectra are recorded on FT-IR Perkin Elmer spectrophotometer RX1 (vmax in $\mathrm{cm}^{-1}$ ) using $\mathrm{KBr}$ disc. ${ }^{1} \mathrm{H}$ NMR spectra are recorded in $\mathrm{CDCl}_{3}$ on a Bruker DRX-300 MHz using TMS as internal standard. The chemical shifts are reported as parts per million (ppm). Magnetic susceptibility measurements were carried out on the vibrating sample magnetometer (VSM) model 155 at 5500 Gauss field strength. Microwave synthesis was carried out in domestic microwave oven model L.G. MS-194W, 230-50Hz, 800W. Beck Man DU-64 Spectrophotometer, with quartz cell of 10mm light path was used for absorption measurement.

\section{Microwave Irradiation synthesis of ligands}

Four ligands i.e. N, N'-bis-(3-carboxy-1-oxopropanyl)-1,2-ethylenediamine(CPE), N,N'-bis(3-carboxy-1-oxo-propanyl)-1,2-phenylenediamine (CPP), N,N'-bis-(2-carboxy-1oxophenelenyl)-1,2-phenylenediamine(CPPP) N,N'-bis-(3-carboxy-1-oxoprop-2-enyl)-1,2phenylenediamine (CPP-2) were synthesized. In a typical preparation mixture of amine (1.0 $\mathrm{mmol}$ ) and carboxylic acid $(2.1 \mathrm{mmol})$ were taken in Erlen Meyer flask capped with a funnel placed in a microwave oven and irradiated at 200 watt for 2 minutes. The reaction was monitored by TLC. After completion the reaction, the reaction mixture was allowed to attain room temperature and solid separated was filtered. The crude product was recrystallized from redistilled ethanol.

\section{Microwave Irradiation synthesis of Mn(II) complexes}

For the preparation of various complexes, a slurry of ligand (i.e. CPE, CPP, CPPP or CPP-2) (1 mmol) was prepared in water or in water-ethanol mixture. In this a solution of $\mathrm{Mn}$ $\left(\mathrm{CH}_{3} \mathrm{COO}\right)_{2} \cdot 4 \mathrm{H}_{2} \mathrm{O}(1 \mathrm{mmol})$ was added. The resulting mixture was irradiated in a microwave oven for 2 to 6 minutes at medium power level $(600 \mathrm{~W})$ maintaining the occasional shaking. The mixture was cooled to room temperature and poured into ice chilled methanol and dried in vacuum over $\mathrm{P}_{2} \mathrm{O}_{5}$. In order to synthesize complexes with CPPP prolonged irradiation and cooling was required.

Complexes and ligands were also synthesized by conventional method and results were found satisfactory. 


\section{Results and Discussion}

Ligands and complexes were identified on the basis of elemental analysis and spectral studies. Colour, yield and elemental analysis data are represented in Table 1.

Vibrational spectra: Few diagnostic IR bands are given in Table $2 \mathrm{v}_{(\mathrm{C}=\mathrm{O})}$ and $\mathrm{v}_{(\mathrm{C}-\mathrm{O})}$ stretching frequencies in the region $1595-1535 \mathrm{~cm}^{-1}$ and $1420-1400 \mathrm{~cm}^{-1}$ observed for free ligands and assigned to asymmetric and symmetric modes respectively are shifted in the complexes. These shifts consequently increase the difference between the frequencies of asymmetric and symmetric modes of carboxylate group known as $\Delta v$. An increase in the value of $\Delta v$ has been ascribed to coordination of carboxylate groups to central metal ion in unidentate fashion. The IR bands due to amide $v_{(\mathrm{N}-\mathrm{H})}$ mode observed at $3397-3209 \mathrm{~cm}^{-1}$ for the free ligands are shifted to higher frequencies indicating non-participation of $\mathrm{N}$ of amide group in coordination. Amide I bands due to $v_{(\mathrm{C}=\mathrm{O})}$ shift negatively opposite to that of $\mathrm{v}_{(\mathrm{N}-\mathrm{H})}$ in the complexes suggesting carbonyl oxygen coordination. Bands observed at $257-224 \mathrm{~cm}^{-1}$ assigned to $\mathrm{v}_{(\mathrm{Mn}-\mathrm{O})}{ }^{7-9}$

Table 2. IR Spectral assignments of diagnostic bands of ligand and its $\mathrm{Mn}$ (II) complexes

\begin{tabular}{llllllll}
\hline S.No. & $\begin{array}{l}\text { Ligand } \\
\text { and } \\
\text { complexes }\end{array}$ & $v_{\mathrm{N}-\mathrm{H}} v_{\mathrm{C}=\mathrm{O}}{ }^{\mathrm{a}}$ & $\left(v_{\mathrm{C}-\mathrm{N}}+\delta_{\mathrm{N}-\mathrm{H}}\right)^{\mathrm{b}}$ & $\left(v_{\left.\mathrm{N}-\mathrm{H}+\delta_{\mathrm{C}-\mathrm{N}}\right)^{\mathrm{c}}}\right.$ & $\begin{array}{l}v_{\mathrm{COO}}{ }^{-} \\
(\text {asym })\end{array}$ & $\begin{array}{l}v_{\mathrm{COO}}{ }^{-} \\
(\mathrm{sym})\end{array}$ & $\left(\mathrm{v}_{\mathrm{Mn}-\mathrm{O}}\right)$ \\
\hline 1 & $\mathrm{CPE}$ & 33031643 & 1428 & 1280 & 1553 & 1419 & --- \\
2 & $\mathrm{Mn}(\mathrm{II})-\mathrm{CPE}$ & 33191610 & 1433 & 1310 & 1560 & 1421 & 247 \\
3 & $\mathrm{CPP}$ & 33771646 & 1461 & 1299 & 1587 & 1419 & --- \\
4 & $\mathrm{Mn}(\mathrm{II})-\mathrm{CPP}$ & 33801606 & 1479 & 1315 & 1596 & 1416 & 257 \\
5 & $\mathrm{CPPP}$ & 33971635 & 1475 & 1301 & 1595 & 1400 & --- \\
6 & $\mathrm{Mn}(\mathrm{II})-\mathrm{CPPP}$ & 34111619 & 1508 & 1312 & 1570 & 1331 & 224 \\
7 & $\mathrm{CPP}-2$ & 32091636 & 1480 & 1280 & 1535 & 1415 & --- \\
8 & $\mathrm{Mn}(\mathrm{II})-\mathrm{CPP} 2$ & 33101621 & 1493 & 1288 & 1541 & 1400 & 248 \\
\hline
\end{tabular}

$\mathrm{a}=$ amide I band $\mathrm{b}=$ amide II band $\mathrm{c}=$ amide III band

Table 1. Physico-Chemical Data of Mn(II) complexes (C.M. = conventional method; M.M. = Microwave method)

\begin{tabular}{|c|c|c|c|c|c|c|c|c|c|}
\hline \multirow{2}{*}{ S.No. } & \multirow{2}{*}{ Complex } & \multirow{2}{*}{ Colour } & \multicolumn{2}{|c|}{$\begin{array}{l}\text { Reaction } \\
\text { Period } \\
\end{array}$} & \multicolumn{2}{|c|}{ Yield (\%) } & \multicolumn{3}{|c|}{$\begin{array}{l}\text { Elemental Analysis } \\
\text { Calcd(Found) }(\%)\end{array}$} \\
\hline & & & $\begin{array}{l}\text { C.M. } \\
\text { (h) }\end{array}$ & $\begin{array}{l}\text { M.M. } \\
(\mathrm{min})\end{array}$ & C.M. & M.M. & $\mathrm{C}$ & $\mathrm{H}$ & $\mathrm{N}$ \\
\hline 1 & $\begin{array}{l}\mathrm{Mn}(\mathrm{II})- \\
\mathrm{CPE}\end{array}$ & $\begin{array}{l}\text { Off } \\
\text { white }\end{array}$ & 2 & 1.5 & 40 & 65 & $\begin{array}{l}38.25 \\
(38.10)\end{array}$ & $\begin{array}{l}5.10 \\
(5.08)\end{array}$ & $\begin{array}{l}5.0 \\
(5.08)\end{array}$ \\
\hline 2 & $\begin{array}{l}\mathrm{Mn}(\mathrm{II})- \\
\mathrm{CPP}\end{array}$ & Brown & 2 & 2 & 30 & 50 & $\begin{array}{l}46.27 \\
(46.29)\end{array}$ & $\begin{array}{l}4.30 \\
(4.41)\end{array}$ & $\begin{array}{l}4.38 \\
(4.41)\end{array}$ \\
\hline 3 & $\begin{array}{l}\mathrm{Mn}(\mathrm{II})- \\
\mathrm{CPPP}\end{array}$ & Brown & 3 & 4 & 20 & 25 & $\begin{array}{l}56.52 \\
(57.33)\end{array}$ & $\begin{array}{l}3.41 \\
(3.48)\end{array}$ & $\begin{array}{l}3.41 \\
(3.48)\end{array}$ \\
\hline 4 & $\begin{array}{l}\mathrm{Mn}(\mathrm{II})- \\
\mathrm{CPP} 2\end{array}$ & Brown & 2 & 1.5 & 30 & 55 & $\begin{array}{l}44.6 \\
(46.81) \\
\end{array}$ & $\begin{array}{l}3.3 \\
(3.34) \\
\end{array}$ & $\begin{array}{l}3.3 \\
(3.34) \\
\end{array}$ \\
\hline
\end{tabular}


Magnetic moments and electronic spectra: Room temperature magnetic moments of the $\mathrm{Mn}$ (II) complexes fall in the range 5.6 - 6.02 BM. These values are typical of tetrahedrally coordinated $\mathrm{Mn}$ which has five unpaired electrons. The visible spectra of these complexes have been measured in methanol are reported in Table 3 . The observed values exhibits bands in the region $20,000 \mathrm{~cm}^{-1}$ to $26,000 \mathrm{~cm}^{-1}$ assignable to ${ }^{6} \mathrm{~A}_{1 \mathrm{~g}} \rightarrow{ }^{4} \mathrm{~T}_{2 \mathrm{~g}}$ and ${ }^{6} \mathrm{~A}_{1 \mathrm{~g}} \rightarrow{ }^{4} \mathrm{E}_{1 \mathrm{~g}}{ }^{4} \mathrm{~A}_{1 \mathrm{~g}}$ transitions. These are also typical of tetrahedral environment around the manganese ${ }^{10-11}$.

Antibacterial activity: The antibacterial activity of the compounds against E.coli and S.aureus were carried out using Muller Hinton Agar media (Hi media). The activity was carried out using paper disc method represented in Table 4. Among the various compounds CPPP and its $\mathrm{Mn}(\mathrm{II})$ complexes has been found out to be most effective against these microbes showing maximum clarity of zones.

Table 3. Magnetic moments and electronic spectral data of the Mn(II) complexes.

\begin{tabular}{|c|c|c|c|c|c|}
\hline S.No. & Complex & $\begin{array}{c}\mu_{\text {eff }} \\
(\mathrm{BM})\end{array}$ & $\begin{array}{c}\text { Electronic } \\
\text { Spectral bands } \\
\lambda \max \left(\mathrm{cm}^{-1}\right)\end{array}$ & $\begin{array}{c}\text { Tentative } \\
\text { assignments }\end{array}$ & Comment \\
\hline 1 & $\mathrm{Mn}(\mathrm{II})-\mathrm{CPE}$ & 5.58 & $\begin{array}{l}26100 \\
20280\end{array}$ & $\begin{array}{c}{ }^{6} \mathrm{~A}_{1 g} \rightarrow{ }^{4} \mathrm{E}_{\mathrm{g}},{ }^{4} \mathrm{~A}_{1 \mathrm{~g}} \\
{ }^{6} \mathrm{~A}_{1 \mathrm{~g}} \rightarrow{ }^{4} \mathrm{~T}_{2 \mathrm{~g}}\end{array}$ & $\begin{array}{c}\text { Tetrahedral } \\
\text { Mn(II) }\end{array}$ \\
\hline 2 & $\mathrm{Mn}$ (II)-CPP & 5.64 & $\begin{array}{l}26310 \\
20050\end{array}$ & $\begin{array}{c}{ }^{6} \mathrm{~A}_{1 g} \rightarrow{ }^{4} \mathrm{E}_{\mathrm{g}},{ }^{4} \mathrm{~A}_{1 \mathrm{~g}} \\
{ }^{6} \mathrm{~A}_{1 \mathrm{~g}} \rightarrow{ }^{4} \mathrm{~T}_{2 \mathrm{~g}}\end{array}$ & $\begin{array}{c}\text { Tetrahedral } \\
\text { Mn(II) }\end{array}$ \\
\hline 3 & Mn (II)- CPPP & 5.70 & $\begin{array}{l}26220 \\
20275\end{array}$ & $\begin{array}{c}{ }^{6} \mathrm{~A}_{1 g} \rightarrow{ }^{4} \mathrm{E}_{\mathrm{g}},{ }^{4} \mathrm{~A}_{1 \mathrm{~g}} \\
{ }^{6} \mathrm{~A}_{1 \mathrm{~g}} \rightarrow{ }^{4} \mathrm{~T}_{2 \mathrm{~g}}\end{array}$ & $\begin{array}{c}\text { Tetrahedral } \\
\text { Mn(II) }\end{array}$ \\
\hline 4 & Mn (II)-CPP-2 & 6.00 & $\begin{array}{l}26218 \\
20100\end{array}$ & $\begin{array}{c}{ }^{6} \mathrm{~A}_{1 g} \rightarrow{ }^{4} \mathrm{E}_{g},{ }^{4} \mathrm{~A}_{1 g} \\
{ }^{6} \mathrm{~A}_{1 g} \rightarrow{ }^{4} \mathrm{~T}_{2 g}\end{array}$ & $\begin{array}{l}\text { Tetrahedral } \\
\text { Mn(II) }\end{array}$ \\
\hline
\end{tabular}

Table 4. Antibacterial activity of synthesized compounds

\begin{tabular}{llll}
\hline S.No. & Compound (100 ppm) & E.coli & S.aureus \\
\hline 1 & CPE & 18 & 10 \\
2 & Mn(II)-CPE & 20 & 14 \\
3 & CPP & 16 & 30 \\
4 & Mn(II)-CPP & 17 & 28 \\
5 & CPPP & 20 & 30 \\
6 & Mn(II)-CPPP & 24 & 32 \\
7 & CPP-2 & 20 & 10 \\
8 & Mn(II)-CPP-2 & 18 & 10 \\
9 & Chloramphenicol & 22 & 20 \\
\hline
\end{tabular}

\section{Conclusions}

$\mathrm{Mn}$ (II) complexes were found to coordinate through amide oxygen and carboxylate oxygens as revealed by the IR spectroscopy. The magnetic moment for all the complexes recorded corresponds to five unpaired electron. Although we were unable to get single crystals for $\mathrm{X}$-ray studies, magnetic, electronic and vibrational spectroscopic data showed the tetrahedral geometry for all the complexes. Tentative structure of complexes is proposed as Fig 1a Mn(II)-CPE, 1 b Mn(II)-CPP, 1c Mn(II)-CPPP, 1d Mn(II)-CPP-2. 

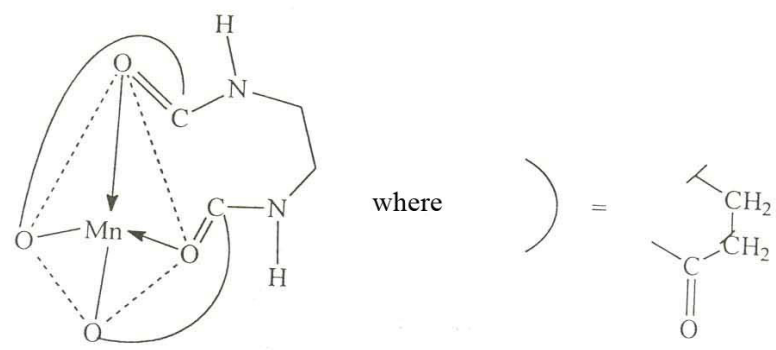

1a

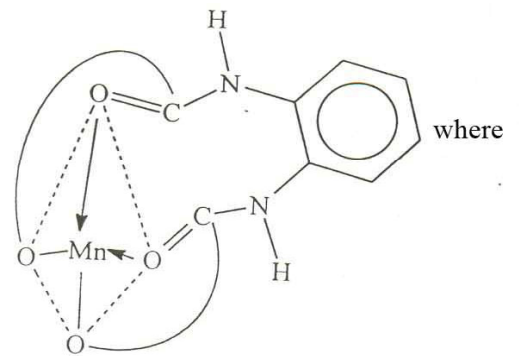<smiles>CCCC(C)=O</smiles>

$1 \mathrm{~b}$

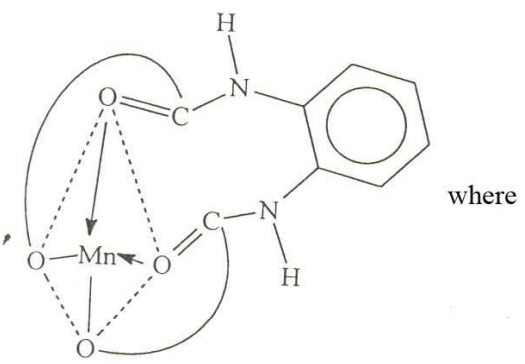

$1 \mathrm{c}$<smiles>CC=CCC</smiles>

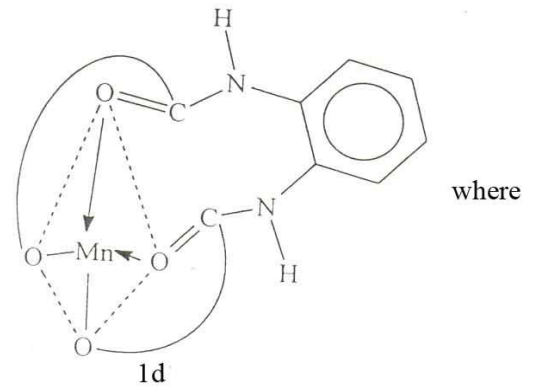

Fig. Tentative structure of complexes

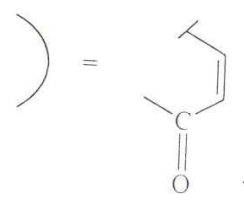

\section{Acknowledgements}

Authors are thankful to SAIF CDRI Lucknow for spectral Analysis. One of the authors (RJ) is thankful to CSIR for SRF 


\section{References}

1. Gotzias G C Fed. Proc. Supplement, 1961, 10, 98.

2. Sauer K, Accts. Chem. Res., 1980, 1, 32.

3. Coleman W M and Taylor L T, Coord Chem. Rev., 1980,32,1.

4. Pecoraro V L, Baker Li X, Butler M J and Bonadies J A, Recueil Trav. Chim., 1987, 106, 221.

5. Garg B S , Bhojak N, Sharma R K, Bist J S and Mittal S, Talanta 1999, 48, 49.

6. Garg B S, Bhojak N, Nandan D, Ind. J. Chem., 2005, 44A, 1504.

7. Sarojini T A and Ramchandra A, Ind J Chem, 1990, 29A,1174.

8. Beukeleer S D, Desseyn H O, Zoupa E M and Perleps S P, Trans. Met. Chem., 1994, 19,468.

9. Nakamoto K, Infrared and Raman Spectra of Inorganic and Coordination Compounds, Wiley-Interscience Publication, 1977, 3

10. Singh R, Sharma K and Fahmi N, Trans. Met.Chem., 1999, 24, 562.

11. Paul R C, Chopra R S, Bhambri R K and Singh G, J. Inorg. Nucl. Chem., 1974, 36, 3703. 


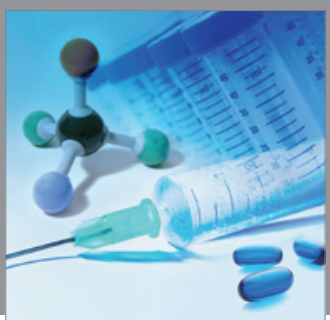

International Journal of

Medicinal Chemistry

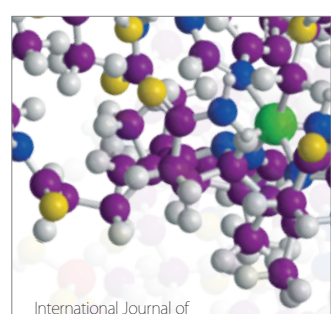

Carbohydrate Chemistry

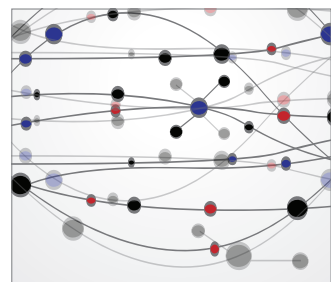

The Scientific World Journal
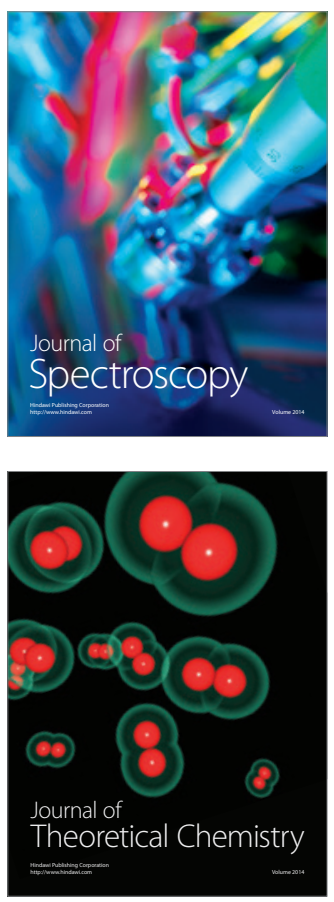
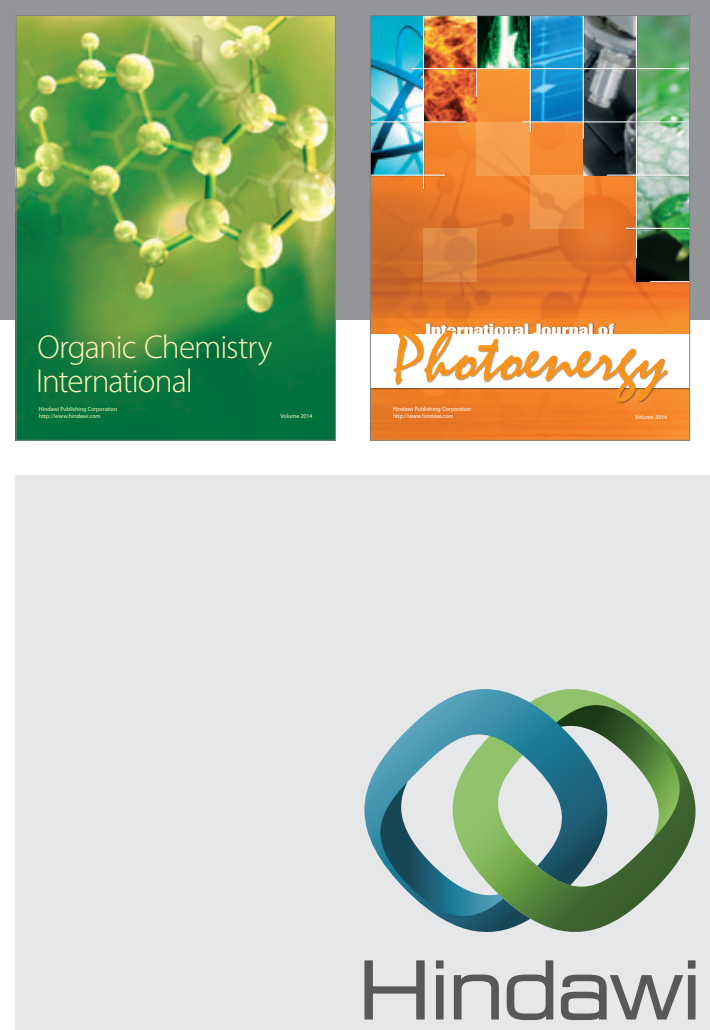

Submit your manuscripts at

http://www.hindawi.com
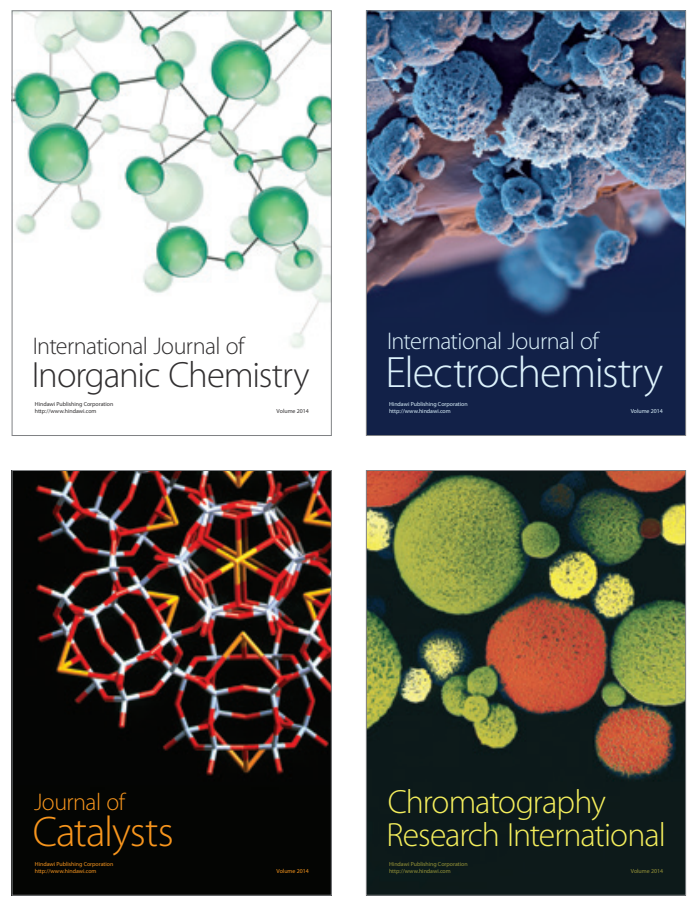
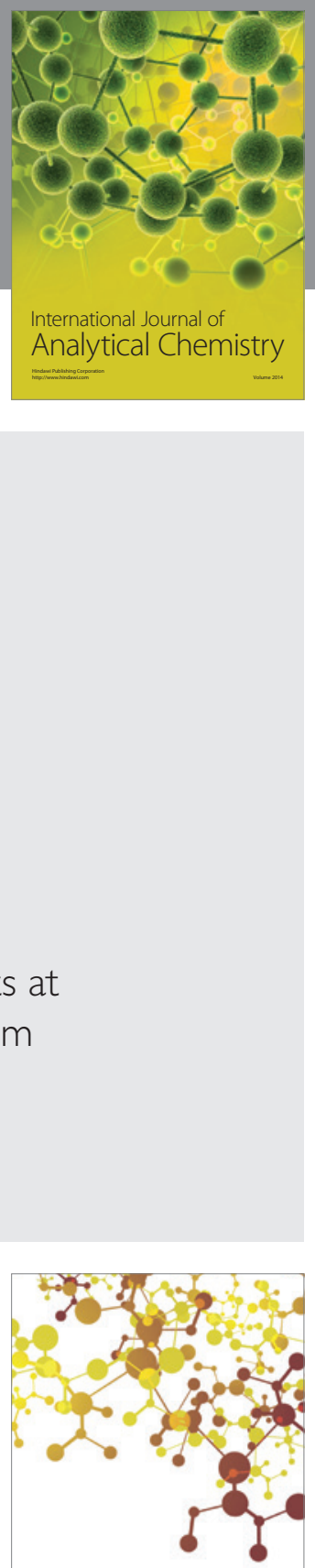

Journal of

Applied Chemistry
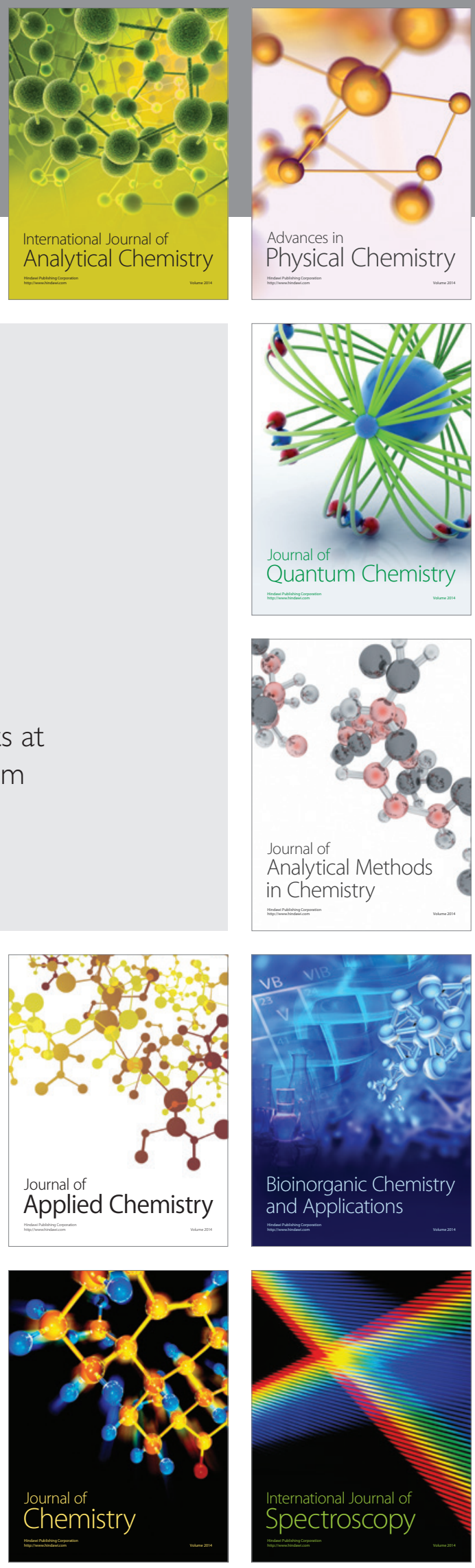